\title{
Biofuel as an Alternative Energy Source for the Automobile Industry: The Experience of the Lower Volga Region (Russia)
}

\author{
N.A. Shyurova ${ }^{1 *}$, V.V. Dubrovin', V.B. Narushev ${ }^{1}$, \\ A.A. Kozhevnikov', I.V. Milovanov' \\ 1 Saratov State Agrarian University named after N.I. Vavilova, Teatralnaya Square, 1, Saratov, 410012, Russia \\ * Corresponding author's e-mail: n.shyurova@bk.ru
}

\begin{abstract}
Currently, the use of biofuel as an alternative energy source for the operation of tractors and cars is becoming increasingly relevant. The use of biofuel is a promising area for the needs of many sectors of the national economy, including the agro-industrial complex. This is due to two problems: first, the global oil reserves are being depleted, and second, the burning of petroleum products causes environmental pollution and serious environmental consequences. The article focuses on the issues of assessing various oil crops for the production of biofuel. In contrast to the favorable conditions in Ukraine, Germany, France, the USA, and Brazil, where rape, soy, and sunflower are used for the production of biofuel, safflower is more suitable for obtaining renewable plant material for the production of biofuel in the arid conditions of cultivation. It has been found that, while many other crops die of drought, safflower forms high and stable yields at the level of $1.2 \mathrm{t} / \mathrm{ha}$, while the more hydrophilous sunflower and spring rape sharply reduce their productivity in arid years -0.8 and $0.5 \mathrm{t} / \mathrm{ha}$, respectively. The research performed by the specialists of the Saratov State Agrarian University (SSAU) during many years have scientifically substantiated the feasibility of growing specifically safflower seeds for the production of biofuel (mixed diesel fuel) in the Lower Volga steppe zone. Safflower oil-based biofuel has low viscosity; it can have a positive effect on the performance of the fuel equipment in tractor units. The performed production tests have shown that when the engine is running on mixed diesel fuel containing $20 \%$ of safflower oil and $80 \%$ of diesel fuel, no reduction of the engine power is observed, while the service life of fuel equipment increases, and the amount of harmful emissions into the atmosphere decreases.
\end{abstract}

Keywords: safflower, biofuel, biodiesel, mixed diesel fuel, arid region, Lower Volga region.

\section{INTRODUCTION}

Currently, the use of biofuel as an alternative source of energy can become the basis for the successful development of many sectors of the national economy. This is due to two serious problems of mankind: first, the global oil reserves are being rapidly depleted, and second, the burning of oil products in modern engines and plants results in environmental pollution [Shpaara, 2006; Zagorodskikh, Kozhevnikov, 2011; Nazarenko, 2012].

Biofuel production setup in Russia is of great economic, commercial, and environmental importance. This issue is especially relevant for agricultural producers since the main consumers of diesel fuel are agricultural machines of various purposes - tractors, combine harvesters, etc. (over $40 \%$ of the total diesel fuel consumption [Shpaara, 2006]), and there is a raw material base for its production. According to the regional Ministry of Agriculture, the annual demand for diesel fuel in the Saratov region exceeds 250 thousand tons. Transferring regional agriculture to biodiesel may save over 150 million rubles a year [Dubrovin, Narushev, 2010]. In the conditions of funds shortage, such savings would allow using the funds for other purposes [Zagorodskikh, Kozhevnikov, 2011]. 
The technology of biodiesel production in all countries where it is used is based on processing rape, sunflower, oil radish, and soybean seeds. Compared to all these oilseed crops, safflower has clear advantages in the Lower Volga region due to a more stable yield in the extremely arid conditions [Kushnir, 2004; Dubrovin, Narushev, 2010; Narushev et al., 2015].

The analysis of the available data shows that, although safflower is especially valuable, the possibility of using safflower oil as biodiesel fuel in the conditions of the Lower Volga region remains insufficiently studied [Zagorodskikh et al., 2009; Zagorodskikh et al., 2010].

\section{MATERIALS AND METHODS}

The research was aimed at developing a technology of cultivating safflower in the Lower Volga steppe zone and using safflower oil in mixed diesel fuel in agricultural production.

The research objectives were the following:

- a comparative study of the adaptive properties of various oil crops cultivated in the Lower Volga region;

- development of a technology for cultivating safflower as a raw material for the production of biodiesel duel in the Saratov region;

- studying the operation of the diesel engine on various fuels; and

- assessing the economic efficiency of cultivating safflower and using it in mixed diesel fuel.

The research aimed at the comparative studying of the adaptive properties of various oil crops and developing a technology of cultivating safflower as a raw material for the production of biodiesel was performed at the experimental field of the SSAU in the Engels district of the Saratov region. The climate in the area was sharply continental. The soil was dark chestnut medium loamy soil. In the field experiments, the generally adopted methodological guidelines were used [Dospekhov, 1985; Dubrovin, 2016].

In order to identify safflower pests and diseases, fields were examined using special techniques [Recommendations for the methodology of observations and research in a field experiment, 1973; Gorbachev et al., 2002; Shakhmedov, 2003; Dubrovin, 2016].

The use of a biofuel based on the oil obtained from safflower seeds was tested at the
Jurgens peasant farm in the Engels district of the Saratov region.

The following was used as fuel for the tractor engine: mineral diesel fuel (DF), the mixture of $80 \%$ of DF and $20 \%$ of safflower oil (SO), and the mixture of $75 \%$ of DF and $25 \%$ of rapeseed oil (RO). The experimental bench consisted of a serial 4CH11.0/12.5 (D-240) diesel engine with sensors installed, a KS-56/4 dynamometric machine with standard instrumentation and an exhaust system, and a complete measuring and recording system (MRS).

All the mechanisms and systems of the engine had been checked and adjusted following the MTZ-80/82 tractor operator's manual.

\section{RESULTS}

The studies performed at the experimental field of the SSAU allowed developing an innovative technology of cultivating safflower seeds to be used for the production of biofuel [Narushev et al., 2010; Narushev et al., 2012a; Narushev et al., 2012b].

The experiments showed that safflower had clear advantages over the other oil crops in the region, the seeds of which might be used for the production of biodiesel, namely, sunflower and rapeseed. Its plants were extremely drought-resistant and could withstand the lack of moisture in the arid zone, while the cultivation of sunflower and especially rapeseed constantly required moisture and many other favorable conditions (Table 1).

A valuable production characteristic of safflower was the annual stable yield of $1.2 \mathrm{t} / \mathrm{ha}$, while the more hydrophilous sunflower and spring rape sharply reduced their productivity in the arid years -0.8 and $0.5 \mathrm{t} / \mathrm{ha}$, respectively.

The most important elements of the developed technology of cultivating safflower seeds for the production of biodiesel were the following:

1. The areas of concentrated safflower cultivation in the Saratov region were identified - they were primarily the steppe areas of the region.

2 . The most suitable domestic varieties were chosen, and the local production of their elite seeds was organized. In the region, it was recommended to improve the production and to widely use the local safflower varieties Ershovsky 4 and Kamyshinsky 73.

3. A resource-saving technology of safflower seed cultivation was developed and introduced, 
Table 1. The characteristics of the oil crops cultivated as a raw material for the production of biodiesel in the Saratov region

\begin{tabular}{|c|c|c|c|}
\hline Indicator & Sunflower & Safflower & Spring rape \\
\hline $\begin{array}{l}\text { Adaptation to the conditions } \\
\text { of the Volga region }\end{array}$ & Medium & High & Weak \\
\hline Moisture requirements & $\begin{array}{l}\text { Demanding - moderately } \\
\text { drought tolerant }\end{array}$ & $\begin{array}{l}\text { Not demanding - drought- } \\
\text { resistant }\end{array}$ & $\begin{array}{l}\text { Hydrophilic - not drought- } \\
\text { resistant }\end{array}$ \\
\hline Nutrition requirements & Needs fertilizers & $\begin{array}{l}\text { Extracts fertilizers well from } \\
\text { the soil }\end{array}$ & Needs fertilizers \\
\hline $\begin{array}{l}\text { Characterization as a } \\
\text { predecessor }\end{array}$ & $\begin{array}{l}\text { Poor - drains and depletes the } \\
\text { soil, harvested late }\end{array}$ & $\begin{array}{l}\text { Good - harvested early, } \\
\text { structures the soil }\end{array}$ & $\begin{array}{l}\text { Medium - harvested early, } \\
\text { structures the soil }\end{array}$ \\
\hline Environmental friendliness & $\begin{array}{l}\text { Medium - needs treatment } \\
\text { with pesticides }\end{array}$ & $\begin{array}{l}\text { Environmentally safe - does } \\
\text { not need treatment with } \\
\text { pesticides }\end{array}$ & $\begin{array}{l}\text { High environmental hazard } \\
\text { - requires many cycles of } \\
\text { treatment with pesticides }\end{array}$ \\
\hline Yield stability & unstable & stable & Extremely unstable \\
\hline The average yield, t/ha & 0.8 & 1.2 & 0.5 \\
\hline
\end{tabular}

which ensured the stable production of highquality renewable plant material for the production of biofuel (biodiesel) that included the following agricultural practices [Narushev et al., 2015]:

- the position in the crop rotation - winter and spring early crops;

- the method of tillage - stubble plowing followed by moldboard plowing to a depth of $22-25 \mathrm{~cm}$; in the spring - harrowing and grubbing;

- the fertilizer rate $-30 \mathrm{~kg}$ of the active substance (nitrogen), $45 \mathrm{~kg}$ of the active substance (phosphorus);

- the optimal time of sowing - early sowing, in the first four to five days of spring field works, simultaneously with the early spring cereal crops;

- the best method of sowing - wide-row sowing with $45 \mathrm{~cm}$ row spacing;

- the optimal seeding rate -250 thousand germinating seeds per hectare;

- crop care - the use of biological products and growth regulators, the use of pesticides only when the economic threshold of harmfulness (ETH) is exceeded; and

- the harvesting method - single-phase.
As a result of regular safflower crop monitoring, it was found that specific safflower pests, namely, Heliothis peltigera, Acanthiophilus helianthi, and Curculionida had virtually not been found on this crop [Dubrovin, 2016; Ismukhambetov, 2008]. At the time of plant branching, powdery mildew in the form of the ashy-white film was found on both sides of the leaves of individual safflower specimens. However, the average intensity of the disease did not exceed one score per plant. Since the observed number of pests did not exceed the ETH (economic threshold of harmfulness), no protective measures were taken. In this regard, a conclusion was drawn that high safflower resistance to pests and diseases allowed avoiding the use of expensive pesticides. At the same time, during the vegetation season, sunflower required at least two, and spring rape - at least four chemical treatment cycles, which increased the costs even further.

At the second stage of the studies, a bench test was performed for studying the use of biodiesel as an alternative fuel for the tractor engine, followed by the comparative characterization of mineral $\mathrm{DF}$, the mixture of $80 \%$ of DF and $20 \%$ of SO, and the mixture of $75 \%$ of DF and $25 \%$ of RO.

The calorific and physical properties of the studied motor fuels are shown in Table 2.

Table 2. The calorific and physical properties of the studied motor fuels

\begin{tabular}{|l|c|c|c|}
\hline \multicolumn{1}{|c|}{ The type of motor fuel } & $\begin{array}{c}\text { The lower calorific } \\
\text { value, } \mathrm{MJ} / \mathrm{kg}\end{array}$ & Density, $\mathrm{kg} / \mathrm{m}^{3}$ & $\begin{array}{c}\text { The kinematic } \\
\text { viscosity, } \mathrm{mm}^{2} / \mathrm{sec}\end{array}$ \\
\hline Mineral diesel fuel & 42.43 & 826 & 4.2 \\
\hline Safflower oil & 36.98 & 913 & 85.6 \\
\hline $\begin{array}{l}\text { The mixture of 20\% of safflower oil and 80\% of diesel } \\
\text { fuel }\end{array}$ & 40.19 & 843 & 35.5 \\
\hline The mixture of 25\% of rape oil and 75\% of diesel fuel & 40.21 & 861 & 42.3 \\
\hline
\end{tabular}


The values obtained during the check test were adopted as the initial data. They met the requirements of the relevant state standards. Before the experiment, the engine had been heated running on DF until the coolant temperature reached $80^{\circ} \mathrm{C}$. After the engine had reached the operating state, the recording of its characteristics started. The following indicators were measured at the experimental bench (at various crankshaft rotation speeds): the effective power, the hourly fuel consumption, and the exhaust smoking.

The results of the experiments are shown in Figures 1, 2, and 3.

It has been found that the hourly fuel consumption by the diesel engine running on the mixture of $80 \%$ of DF and $20 \%$ of SO increases on average by $2 \%$, compared to DF, and decreases by $1.5 \%$, compared to the mixture of $75 \%$ of DF and $25 \%$ of RO. The effective power of the diesel engine running on the mixture of $80 \%$ of DF and $20 \%$ of SO decreases by $1.6 \%$, compared to DF, and by $1 \%$, compared to the mixture of $75 \%$ of DF and $25 \%$ of RO. The exhaust smoking of the diesel engine running on the mixture of $80 \%$ of
DF and $20 \%$ of SO decreases by $19 \%$, compared to $\mathrm{DF}$, and by $13 \%$, compared to the mixture of $75 \%$ of DF and $25 \%$ of RO. With the mixed DF heater used on the tractor, the annual cost savings amount to 5,965 rubles per one MTZ-80 tractor, and $20 \%$ of the DF is saved. The tests have shown that the diesel engine operation on SO is comparable to its operation on DF. With that, there is no need to upgrade the engine.

According to the long-term average data, the oil yields of safflower and sunflower are the same - 444 and $4001 /$ ha, respectively, while that of rapeseed is twice lower - only $2401 /$ ha. However, the cost of producing one liter of oil from safflower is twice lower, compared to sunflower, and four times lower, compared to rapeseed (Table 3).

\section{DISCUSSION}

The global reserves of organic biomass for the production of biofuel are very high. These include a large amount of various raw materials - leaves, stems, and seeds. Processing them rationally

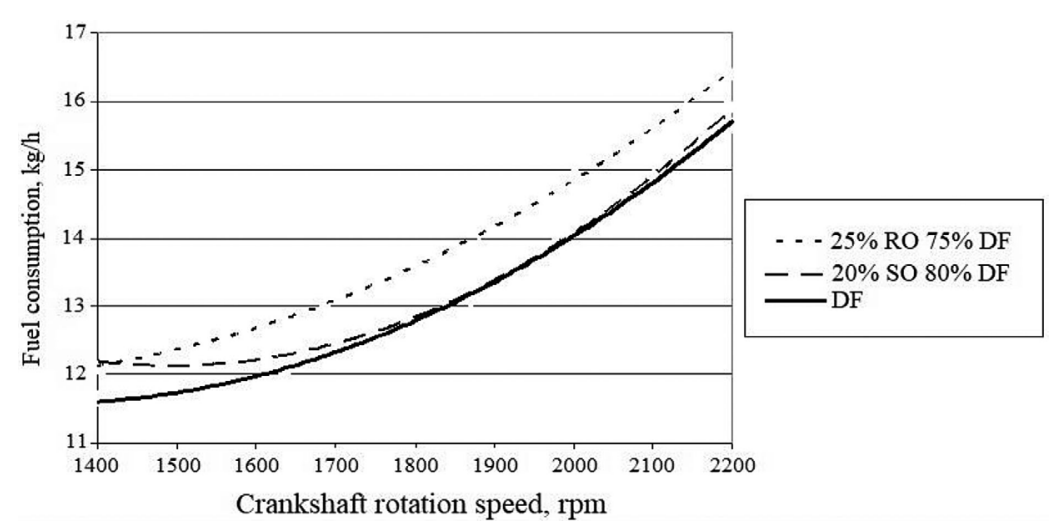

Figure 1. Changes in the hourly fuel consumption in the conditions of the regulatory characteristic of the D-240 diesel engine

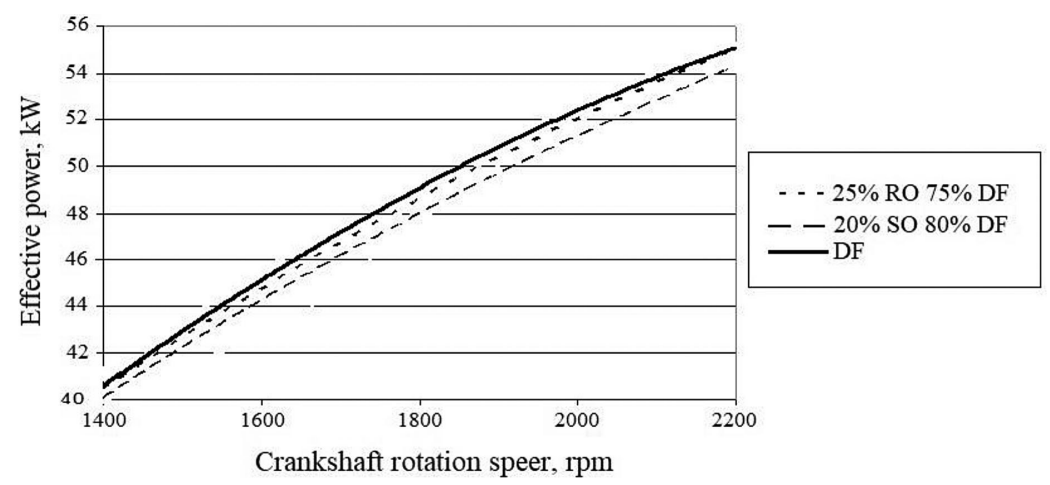

Figure 2. Changes in the effective power in the conditions of the regulatory characteristic of the D-240 diesel engine 


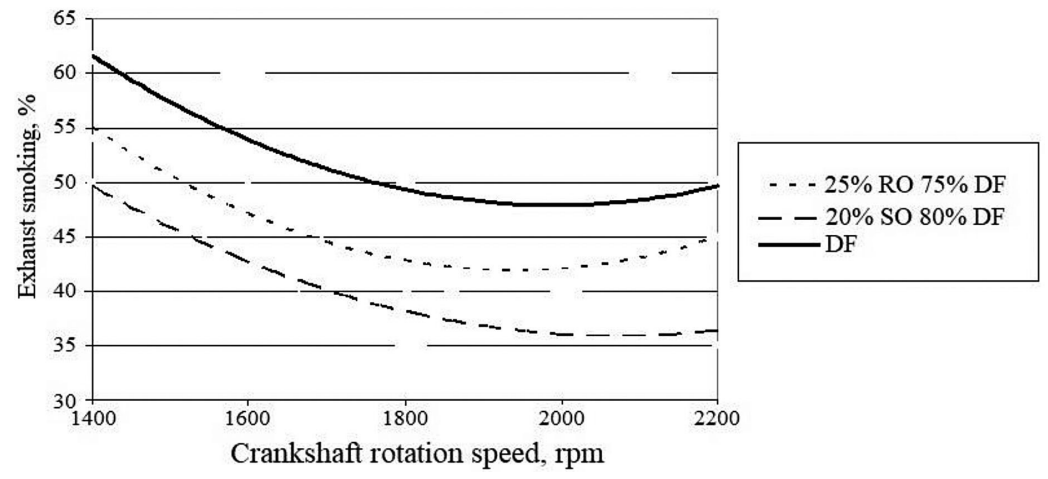

Figure 3. Changes in the exhaust smoking in the conditions of the regulatory characteristic of the D-240 diesel engine

would partially solve the energy problem, especially in the remote regions of many countries where the delivery of DF is expensive and is often fraught with transportation difficulties [Dublyanskaya, Malysheva, 1964]. This also fully applies to many agricultural regions of Russia.

Europe is one of the main biofuel consumers; however, it cannot afford to allocate the required acreage for cultivating the crops for biofuel production. At the same time, in Russia, the significant acreage that could be allocated for growing crops for these purposes remains unused.

The prospects of extensive and successful safflower cultivation in the Lower Volga region are determined by the following factors:

- agrobiological factors - the Saratov region is the Lower Volga region where safflower cultivation is the most appropriate, given its drought resistance and indiscriminateness to the soil fertility;

- agrotechnical factors - due to its early harvesting time and a positive effect on soil fertility, safflower is a good predecessor, which can increase the efficiency of the zonal crop rotations; and

- economic factors - safflower seeds are in high demand both in the domestic and foreign markets due to their limited supply.

The Saratov region as a whole has the necessary resources for reaching a high level of production of safflower seeds, which are the most suitable for the production of biofuel.

The most available and easiest way of the vegetable oils practical use in the form of energy material is using them as an additive to DF. In recent years, mixed DFs based on vegetable oils

Table 3. The economic indicators of biodiesel production from various oilseeds in the Saratov region

\begin{tabular}{|l|c|c|c|}
\hline \multicolumn{1}{|c|}{ Indicator } & Sunflower & Safflower & Spring rape \\
\hline \multicolumn{2}{|c|}{ Long-time average annual data } \\
\hline Yield, t/ha & 0.8 & 1.2 & 0.5 \\
\hline Oil content, \% & 50 & 37 & 40 \\
\hline Oil yield from 1 ha, I & 400 & 444 & 200 \\
\hline The direct cost of cultivation, rubles/ha & 6,500 & 4,000 & 30.000 \\
\hline $\begin{array}{l}\text { The cost of production of one liter of oil, } \\
\text { rubles }\end{array}$ & 16.25 & 9.01 & \\
\hline & Arid year & & \\
\hline Yield, t/ha & 0.4 & 37 & 40.2 \\
\hline Oil content, \% & 50 & 444 & 80 \\
\hline Oil yield from 1 ha, I & 200 & 4,000 & 6,000 \\
\hline The direct cost of cultivation, rubles/ha & 6,500 & 9.01 & 75.0 \\
\hline $\begin{array}{l}\text { The cost of production of one liter of oil, } \\
\text { rubles }\end{array}$ & 32.5 & & \\
\hline
\end{tabular}


(e.g., rapeseed, soybean, sunflower, peanut, and palm oil) and their derivatives have been widely used [Shpaara, 2006; Nazarenko, 2012].

Currently in Europe (Germany, France, Austria, etc.), more than 1.5 million tons of mixed DF are produced [Zagorodskikh et al., 2009; Nazarenko, 2012]. As shown by more than 20 years of experience in operating diesel engines of various purposes, their conversion to mixed DF does not require changing the design of the diesel engines.

The tests performed by the scientists at the SSAU showed that the mixed biofuel based on SO had low viscosity, and this fact had a positive effect on the performance of the fuel equipment in tractor units. Running the engine on the mixed fuel consisting of $20 \%$ of SO and $80 \%$ of DF did not reduce the engine power. With that, the service life of the fuel equipment increased, and the harmful emissions into the atmosphere decreased. The diesel engine operation on SO was comparable to its operation on DF; with that, no engine upgrade was needed.

\section{CONCLUSION}

Thus, the advantages of obtaining biodiesel from the renewable plant material in the Lower Volga region are obvious. With that, in the arid conditions of the Saratov region, it is only the safflower that can consistently supply high-quality oil-bearing raw material for the production of biodiesel, and the use of the biofuel obtained by mixing DF with SO is highly important, both economically and commercially.

\section{REFERENCES}

1. Dospekhov B.A. 1985. Metodika polevogo opyta [The methodology of field experiment]. Moscow: Kolos (in Russian).

2. Dublyanskaya N.F., Malysheva A.G. 1964. Biokhimicheskie osobennosti osnovnykh maslichnykh kultur SSSR [Biochemical features of the major oilseed crops in the USSR]. Oilseed and essential oil crops. Moscow: Kolos, 12-15 (in Russian).

3. Dubrovin V.V. 2016. Organizatsiya zashchity rastenii ot vrednykh organizmov [Organization of plant protection from harmful organisms]. FSBEI HE Saratov State Agrarian University, Saratov (in Russian).
4. Dubrovin V.V., Narushev V.B. 2010. Perspektivy ispolzovaniya saflora pri proizvodstve biotopliva $\mathrm{V}$ usloviyakh Saratovskogo Zavolzhya [The prospects of using safflower for the production of biofuel in the conditions of the Trans-Volga part of the Saratov region]. The introduction of environmentally safe technologies for integrated plant protection: Materials of the International Scientific and Practical Conference - Saratov, KUBiK Publishing house, 25-26 (in Russian).

5. Gorbachev I.V., Gritsenko V.V., Zachvatkin Y.A. 2002. Zashchita rastenii ot vreditelei [Plant protection from pests]. Moscow: Kolos (in Russian).

6. Ismukhambetov Z.D. 2008. Vrediteli saflora [Safflower pests]. Plant protection and quarantine, 2, 57-58 (in Russian).

7. Kushnir A.S. 2004. Nekotorye tekhnologicheskie aspekty vozdelyvaniya maslichnykh kultur v Volgogradskoi oblasti [Some technological aspects of oilseed cultivation in the Volgograd region]. Fundamentals of achieving sustainable agricultural development: Materials of the conference dedicated to the 60th anniversary of founding the Volgograd State Academy of Agriculture. The Agronomy and livestock farming section. Volgograd (in Russian).

8. Narushev V. B., Kuanyshkaliev A. T., Mazhaev N. I. et al. (Eds.). 2012a. Nauchno-prakticheskie osnovy adaptivnoi tekhnologii vozdelyvaniya saflora v Saratovskoi oblasti: Uchebno-metodicheskie rekomendatsii [The scientific and practical bases of an adaptive technology of cultivating safflower in the Saratov region: Teaching guidelines]. Saratov: Publishing House of the SSAU (in Russian).

9. Narushev V.B., Eskov I.D., Dubrovin V.V., Kuanyshkaliev A.T. et al. 2015. Tekhnologiya vyrashchivaniya semyan saflora dlya proizvodstva biotopliva v Stepnom Povolzhye [The technology of cultivating safflower seeds for the production of biofuel in the steppe Volga region]. Scientific and practical recommendations. Saratov: The Orion Publishing House (in Russian).

10. Narushev V.B., Gorshenin D.V., Kutyrev V.I., Popov D.V. 2010. Razrabotka priemov vozdelyvaniya maslichnykh kultur po mikrozonam Saratovskoi oblasti [Development of the methods of oilseed crops cultivation in the microzones of the Saratov region]. Materials of the International scientificpractical conference Vavilov Readings-2010. Saratov, 10-11 (in Russian).

11. Narushev V.B., Kuanyshkaliev A.T., Gorshein D.A., Mazhaev N.I. 2012b. Rasshirenie bioraznoobraziya vozdelyvaemykh maslichnykh kultur v stepnom Povolzhye [Expanding the biodiversity of the cultivated oilseed crops in the steppe Volga region]. Bulletin of the SSAU, 10, 59-61 (in Russian). 
12. Nazarenko L.V. 2012. Biotoplivo: istoriya i klassifikatsiya vidov biotopliva [Biofuel: history and classification]. Bulletin of the Moscow City University. The Natural Sciences series, 2(10), 16-32.

13. Rekomendatsii po metodike provedeniya nablyudenii i issledovanii $\mathrm{v}$ polevom opyte [Recommendations for the methodology of observations and research in a field experiment]. 1973. Agricultural Research Institute of South-East Region. Saratov: The Privolzhskoye book publishing house (in Russian).

14. Shakhmedov I.S. 2003. Rekomendatsii po vozdelyvaniyu saflora [Recommendations for safflower cultivation]. The species diversity and the dynamics of natural and industrial complexes development in the Lower Volga region. The Caspian Research Institute of Arid Agriculture (PNIIAZ), 1, 493-499 (in Russian).
15. Shpaara D. (Ed.). 2006. Vozobnovlyaemoe rastitelnoe syrye [Renewable plant raw materials]. SaintPetersburg - Pushkin (in Russian).

16. Zagorodskikh B.P., Kozhevikov A.A., Fadeev S.A. 2010. Saflorovoe maslo vmesto rapsovogo [Safflower oil instead of rapeseed oil]. Rural machine operator, 6, 34-35 (in Russian).

17. Zagorodskikh B.P., Kozhevnikov A.A. (Eds.). 2011. Adaptatsiya toplivnoi apparatury traktornykh dvigatelei dlya raboty na biotoplive. Rekomendatsii proizvodstvu [Adaptation of tractor engine fuel equipment for running on biofuel. Production recommendations]. Saratov (in Russian).

18. Zagorodskikh B.P., Tokhiyan M.K., Kozhevikov A.A., Chugunov V.A. 2009. Biotoplivo dlya dizelei na osnove saflorovogo masla [Safflower oil-based biofuel for diesel engines]. Niva Povolzhya, 4(13), 71-74 (in Russian). 